\title{
Fundus Fluorescein Angiography Versus Optical Coherence Tomography Angiography in Evaluation of Retinal Changes in Cases of Retinal Vein Occlusion
}

\author{
HASHEM H. GHORABA, M.Sc.; MOSTAFA A. ABO EL-ENIN, M.D.; MAGDY S. MOUSSA, M.D. and \\ TAMER E. WASFY, M.D.
}

The Department of Ophthalmology, Faculty of Medicine, Tanta University, Tanta, Egypt

\begin{abstract}
Background: Retinal Vein Occlusion (RVO) is the second most common retinal vascular disease and the fifth common cause of visual loss worldwide. Fundus Fluorescein Angiography (FFA) is the gold standard investigation for its evaluation. However, it has some limitations. Optical Coherence Tomography Angiography (OCTA) is a novel technique for evaluation of retinal vascular changes. It may overcome some of the limitations of FFA.
\end{abstract}

Objective: Comparison between FFA and OCTA in evaluation of retinal changes in retinal vein occlusion.

Methods: This prospective observational case series study was carried out on 30 eyes of 29 patients attending Ophthalmology Outpatient Clinic in Tanta University Hospital from July 2016 to May 2017. FFA and OCTA were done to all patients at time of diagnosis. The results of both modalities were compared regarding macular ischemia, macular edema, microaneurysms, collaterals and neovascularizations.

Results: OCTA detected macular ischemia in the superficial plexus of 17 cases while it detected ischemia in the deep plexus of 25 cases. FFA detected macular ischemia in 9 cases and couldn't comment on ischemia in 5 cases. FFA detected macular edema in 23 cases while OCTA detected only 20 cases. Both collaterals and neovascularizations were detected in 3 separate cases by both OCTA and FFA. Microaneurysms were detected in 8 cases by FFA and in 4 cases by OCTA.

Conclusion: OCTA was superior to FFA in detection of macular ischemia. Both modalities were equal in detection of macular edema, collaterals and neovascularizations. FFA was superior in detection of microaneurysms.

Key Words: OCTA - FFA - Retinal vein occlusion.

\section{Introduction}

RETINAL Vein Occlusion (RVO) is the second most common retinal vascular disease. It can be classified anatomically into Central Retinal Vein

Correspondence to: Dr. Hashem H. Ghoraba,

The Department of Ophthalmology, Faculty of Medicine, Tanta University, Tanta, Egypt
Occlusion (CRVO), Hemiretinal Vein Occlusion (HRVO) and Branch Retinal Vein Occlusion (BR$\mathrm{VO}$ ) and pathophysiologically into ischemic and non ischemic [1].

Retinal vein occlusions can be considered as a localized retinal manifestation of a systemic vasculopathy or coagulopathy. The most important risk factor is hypertension. Other risk factors include diabetes mellitus, hyperlipidemia and hypercoaguable states [2].

However, local ocular risk factors such as glaucoma and hyperopia are associated with retinal vein occlusion [2].

Since its 1 st appearance in early 1960s, Fundus Fluorescein Angiography (FFA) has been an essential tool in the assessment of retinal vascular diseases [3].

It provided essential data regarding vascular state of retina, detection of microaneurysms, neovascularization, macular edema, areas of nonperfusion and other vascular changes in retinal vascular diseases [4-8]

Nevertheless, FFA is not without problems; some patients have contraindications to the dye such as those with hypersensitivity to fluorescein [9].

Moreover, analysis of level of retinal pathology is not possible as this imaging modality is not depth resolved [10]

Optical Coherence Tomography Angiography (OCTA) is introduced for clinical application in 2015. It is safe non-invasive, non-dye based imaging technique of retinal and choroidal vasculature 
that is based on multiple consecutive Optical Coherence Tomography (OCT) B-scans compared regarding decorrelation signal to detect motion contrast [10].

Optical coherence tomography angiography has the potential to be used as a clinical tool for RVO diagnosis and follow-up, providing vascular details that have not been previously observed by standard FFA [11]

\section{Patients and Methods}

This prospective observational case series study was carried out on 30 eyes of 29 patients who were clinically diagnosed with any type of retinal vein occlusion in ophthalmology Tanta University Hospital Outpatient Clinic from July 2016 to May 2017. The main exclusion criteria were any type of treatment for RVO as argon laser photocoagulation and intravitreal injections, severe complications of RVO as neovascular glaucoma, significant media opacities as cataract that will affect the quality of the images, any contraindication for intravenous fluorescein as renal impairment and hypersensitivity and diabetes mellitus to avoid confounding.

All patients were subjected to full clinical examination. Investigations were done simultaneously. Those included FFA, OCTA and Optical Coherence Tomography (OCT).

FFA was done using Topcon TRC-50DX, (Topcon Corp, Tokyo, Japan). Both OCT and OCTA were performed using swept source Topcon OCT Triton OCTA (Topcon Corp, Tokyo, Japan) was performed using $6 \times 6 \mathrm{~mm}$ scan centered on the fovea in all cases with additional $3 \times 3 \mathrm{~mm}$ and/or $9 \times 9 \mathrm{~mm}$ in some cases. The macula was assessed in 2 zones; the superficial plexus extending from internal limiting membrane to inner plexiform layer and the deep plexus extending from inner plexiform layer to outer plexiform layer.

The data gained from FFA were compared to that gained from OCTA regarding:

- Capillary non perfusion and retinal ischemia. Cases of CRVO and BRVO were considered ischemic if retinal ischemia by FFA was $\geq 10$ and 5 disc areas respectively.

Macular ischemia was studied independently from the general ischemic condition of the retina. In FFA, macular ischemia was diagnosed whenever an area of hypofluorescence, not attributed to hemorrhage, was present in the macular area. In
OCTA, macular ischemia was diagnosed as decreased OCTA signal not attributed to hemorrhage.

- Macular edema, which is controlled by OCT images. In FFA, macular edema is defined as dye leakage in the mid phase. In OCTA, macular edema is diagnosed as cystic spaces devoid of OCTA signals. In OCT, edema is defined as hyporeflective spaces and/or retinal thickening.

- Microaneurysms.

- Collaterals.

- Neovascularizations.

\section{Results}

The study involved different types of RVO; 12 cases of CRVO, 15 cases of BRVO including 6 macular BRVO and 3 cases of HRVO.

Retinal ischemia: In the superficial plexus, OCTA detected ischemia in 17 cases while it detected macular ischemia in the deep plexus in 25 cases. All cases that had ischemia in superficial plexus showed deep ischemia. Macular ischemia was detected in spite of macular hemorrhage. The difference between the 2 plexuses was statistically significant. See (Table 1).

However, FFA detected macular ischemia in 9 cases, revealed no macular ischemia in 16 cases and couldn't comment on macular ischemia-due to hemorrhage-in 5 cases.

FFA also detected extensive peripheral ischemia in 8 cases (which were considered ischemic RVOs) but OCTA didn't evaluate peripheral ischemia in all cases due to its narrow field.

About 10 cases showed intraretinal hemorrhage involving the macula with 5 of them having significant hemorrhage to obscure the macular view. FFA couldn't evaluate ischemia in them but OCTA was able to detect ischemia in all of them.

Table (2) summarizes the difference between FFA and OCTA in macular ischemia.

In 2 cases that were diagnosed as CRVO, Paracentral Acute Middle Maculopathy (PAMM) was diagnosed based on OCT that showed in B scan multiple hyperreflective patches in the middle retina that was not presented in the FFA. In OCTA, superficial plexus showed no ischemia while the deep plexus showed significant ischemia. While in enface OCT, the middle plexus showed multiple hyperreflective patches corresponding to those found in conventional B scans. 
Relationship between the type of RVO (ischemic or non ischemic) and macular ischemia:

In FFA, macular ischemia was detected in 9 cases. This involves all the 8 ischemic cases and 1 case classified as non ischemic. However, OCTA detected macular ischemia in the superficial plexus in 17 cases. This involves all the 8 ischemic cases, 5 non ischemic and 4 indeterminate. Nevertheless, OCTA showed ischemia in the deep plexus in 25 cases which involved all 8 ischemic cases, all 5 indeterminate cases and 12 non-ischemic cases. See (Tables 3-5).

Macular edema: Macular edema was confirmed in 25 cases using conventional OCT B scans. FFA detected macular edema as leakage in the macular area in mid phase in 23 cases of the 25 cases diagnosed by OCT. This includes cases where dense hemorrhage involved the macula.

However, OCTA could only reveal macular edema in 20 cases of the 25 cases. Edema was defined as cystic areas of decreased OCTA signal. The difference between FA and OCTA in detection of macular edema was statistically insignificant. See (Table 6).

Enface OCT images, when compared with OCTA images, confirmed the presence of macular edema when ischemia was a potential cause of decreased OCTA signal intensity. Edema appears as hyporeflective areas which is not the case in ischemia.

\section{Microaneurysms:}

FFA could detect microaneurysms in 8 cases while OCTA could only detect them in 6 of these cases. The number of microaneurysms detected by FFA also was significantly higher and of better resolution.

Some of the microaneurysms detected by FFA were not associated with significant retinal leakage. And some of these weren't detected by OCTA.

Another interesting finding is that in the 6 cases with microaneurysms detected by OCTA, most of them were more at the level of deep capillary plexus not the superficial one.

Retinal neovascularization: Both FA and OCTA could detect Neovascularization Elsewhere (NVEs) in 3 cases. In one case FFA showed also Neovascularization on Disc (NVDs) that was not seen in OCTA as the disc was outside the field.

Collaterals: Both FFA and OCTA detected collateral vessels in 3 cases only. OCTA was able to provide data regarding level of the collateral vessels which was not available by FFA.

\section{Relationship between macular Ischemia and VA:}

After exclusion of cases with both macular hemorrhage and ischemia detected by FFA, a statistically significant difference was found between mean visual acuity in cases with macular ischemia detected by FFA and mean visual acuity in cases in which FFA didn't detect macular ischemia. A negative relation was found between mean visual acuity and macular ischemia detected by FFA. See (Table 7).

Also, after exclusion of cases with significant macular hemorrhage, a statistically significant negative relation was found between mean visual acuity mean and ischemia in the superficial plexus detected by OCTA. See (Table 8).

Also, after exclusion of cases with significant macular hemorrhage, a stronger statistically significant negative relation was found between mean visual acuity mean and ischemia in the deep plexus detected by OCTA. See (Table 9).

\section{Relationship between macular Ischemia and VA:}

No statistically significant relation was found between macular ischemia detected by FFA and macular thickness. See (Table 10).

The same data applied to ischemia in the superficial plexus by OCTA where no statistically significant relation was found with macular thickness. See (Table 11).

However, a statistically significant positive relation was found between ischemia found in the deep plexus by OCTA and macular thickness. See (Table 12).

Table (1): Macular ischemia by OCTA.

\begin{tabular}{|c|c|c|}
\hline Ischemia by OCTA & Number & Percentage \\
\hline \multicolumn{3}{|c|}{ Ischemia in superficial plexus: } \\
\hline No ischemia & 13 & $43.3 \%$ \\
\hline Ischemia & 17 & $56.7 \%$ \\
\hline \multicolumn{3}{|c|}{ Ischemia in deep plexus: } \\
\hline No ischemia & 5 & $16.7 \%$ \\
\hline Ischemia & 25 & $83.3 \%$ \\
\hline Z-test & \multirow{2}{*}{\multicolumn{2}{|c|}{6.857}} \\
\hline$p$-value & & \\
\hline
\end{tabular}

Table (2): Macular ischemia by both FFA and OCTA.

\begin{tabular}{lll}
\hline Macular ischemia & FFA & OCTA \\
\hline Equivocal & $5(16.7 \%)$ & $0(0 \%)$ \\
No ischemia & $16(53.3 \%)$ & $5(16.7 \%)$ \\
Macular ischemia & $9(30 \%)$ & $25(83.3 \%)$ \\
Z-test & \multicolumn{2}{c}{$14.994^{2}$} \\
$p$-value & \multicolumn{2}{c}{$0.001^{*}$} \\
\hline
\end{tabular}


Table (3): Percentage of macular ischemia by FFA after classification of cases according to ischemic condition.

\begin{tabular}{|c|c|c|c|c|}
\hline \multirow{2}{*}{$\begin{array}{l}\text { Type of RVO } \\
\text { (ischemic vs } \\
\text { non ischemic) }\end{array}$} & \multicolumn{3}{|c|}{ Macular ischemia by FFA } & \multirow{2}{*}{$\chi^{2}$} \\
\hline & $\begin{array}{l}\text { Ischemia } \\
\quad(n=9)\end{array}$ & $\begin{array}{l}\text { No ischemia } \\
\quad(\mathrm{n}=16)\end{array}$ & $\begin{array}{l}\text { Equivocal } \\
\qquad(\mathrm{n}=5)\end{array}$ & \\
\hline $\begin{array}{l}\text { - Ischemic } \\
(\mathrm{n}=8)\end{array}$ & $\begin{array}{l}8 \\
(100.0 \%)\end{array}$ & $\begin{array}{l}0 \\
(0.0 \%)\end{array}$ & $\begin{array}{l}0 \\
(0.0 \%)\end{array}$ & 49.9840 .001 \\
\hline $\begin{array}{l}\cdot \text { Non ischemic } \\
(\mathrm{n}=17)\end{array}$ & $\begin{array}{l}1 \\
(5.9 \%)\end{array}$ & $\begin{array}{l}16 \\
(94.1 \%)\end{array}$ & $\begin{array}{l}0 \\
(0.0 \%)\end{array}$ & \\
\hline $\begin{array}{l}\text { - Indeterminate } \\
(\mathrm{n}=5)\end{array}$ & $\begin{array}{l}0 \\
(0.0 \%)\end{array}$ & $\begin{array}{l}0 \\
(0.0 \%)\end{array}$ & $\begin{array}{l}5 \\
(100.0 \%)\end{array}$ & \\
\hline
\end{tabular}

$\chi^{2}:$ Chi square.

Table (4): Percentage of ischemia in superficial plexus by OCTA after classification of cases according to ischemic condition.

\begin{tabular}{|c|c|c|c|}
\hline \multirow{2}{*}{$\begin{array}{l}\text { Type of RVO } \\
\text { (ischemic vs } \\
\text { non ischemic) }\end{array}$} & \multicolumn{2}{|c|}{$\begin{array}{l}\text { Ischemia in superficial } \\
\text { plexus by OCTA }\end{array}$} & \multirow{2}{*}{$x^{2}$} \\
\hline & $\begin{array}{l}\text { Ischemia } \\
(\mathrm{n}=17)\end{array}$ & $\begin{array}{l}\text { No ischemia } \\
\quad(\mathrm{n}=13)\end{array}$ & \\
\hline Ischemic $(\mathrm{n}=8)$ & $8(100.0 \%)$ & $0(0.0 \%)$ & $10.9980 .001 *$ \\
\hline Non ischemic $(n=17)$ & $5(29.4 \%)$ & $12(70.6 \%)$ & \\
\hline Indeterminate $(\mathrm{n}=5)$ & $4(80.0 \%)$ & $1(20.0 \%)$ & \\
\hline
\end{tabular}

$\chi^{2}:$ Chi square.

Table (5): Percentage of ischemia in deep plexus by OCTA after classification of cases according to ischemic condition.

\begin{tabular}{lllll}
\hline \multirow{2}{*}{$\begin{array}{l}\text { Type of RVO } \\
\text { (ischemic vs } \\
\text { non ischemic) }\end{array}$} & \multicolumn{2}{c}{$\begin{array}{c}\text { Ischemia in superficial } \\
\text { plexus by OCTA }\end{array}$} & & \\
\cline { 2 - 3 } & $\begin{array}{c}\text { Ischemia } \\
(\mathrm{n}=25)\end{array}$ & $\begin{array}{c}\text { No ischemia } \\
(\mathrm{n}=5)\end{array}$ & & $p$ \\
\hline Ischemic $(\mathrm{n}=8)$ & $8(100.0 \%)$ & $0(0.0 \%)$ & 2.210 & 0.330 \\
Non ischemic $(\mathrm{n}=17)$ & $12(70.6 \%)$ & $5(29.4 \%)$ & & \\
Indeterminate $(\mathrm{n}=5)$ & $5(100.0 \%)$ & $0(00.0 \%)$ & & \\
\hline 2
\end{tabular}

$\chi^{2}:$ Chi square.

Table (6): Macular edema by OCT, FFA and OCTA.

\begin{tabular}{lcccc}
\hline \multirow{2}{*}{$\begin{array}{l}\text { Diagnostic } \\
\text { procedure }\end{array}$} & \multicolumn{2}{c}{ Edema } & Z-test & $p$-value \\
\cline { 2 - 4 } & $\mathrm{N}$. & $\%$ & & - \\
\hline OCT & 25 & 83.3 & - & 0.390 \\
FA & 23 & 76.7 & 0.739 & \\
OCTA & 20 & 66.7 & & \\
\hline
\end{tabular}

Table (7): Relation between visual acuity and macular ischemia detected by FFA.

\begin{tabular}{lcccc}
\hline FA & $\begin{array}{c}\text { Ischemia } \\
\mathrm{n}=8\end{array}$ & $\begin{array}{c}\text { No ischemia } \\
\mathrm{n}=17\end{array}$ & $t$-test & $p$-value \\
\hline $\begin{array}{l}\text { Mean visual } \\
\text { acuity } \pm \text { S.D }\end{array}$ & $0.11 \pm 0.08$ & $0.24 \pm 0.13$ & -2.872 & $0.009^{*}$ \\
\hline
\end{tabular}

$t$ : Independent sample $t$-test.
Table (8): Relation between ischemia in the superficial plexus detected by OCTA and VA.

\begin{tabular}{lcccc}
\hline OCTA & $\begin{array}{c}\text { Ischemia } \\
\mathrm{n}=13\end{array}$ & $\begin{array}{c}\text { No ischemia } \\
\mathrm{n}=12\end{array}$ & $t$ & $p$ \\
\hline $\begin{array}{l}\text { Mean visual } \\
\text { acuity } \pm \text { S.D }\end{array}$ & $0.14 \pm 0.09$ & $0.28 \pm 0.14$ & -2.916 & $0.009^{*}$ \\
\hline$t$ : Independent sample $t$-test. & & \\
$\begin{array}{l}\text { Table (9): Relation between ischemia in the deep plexus } \\
\text { detected by OCTA and VA. }\end{array}$ \\
$\begin{array}{l}\text { Ischemia } \\
\mathrm{n}=21\end{array}$ & $\begin{array}{c}\text { No ischemia } \\
\mathrm{n}=4\end{array}$ & $t$ & $p$ \\
OCTA & $0.16 \pm 0.1$ & $0.42 \pm 0.1$ & -4.701 & $0.008^{*}$ \\
\hline $\begin{array}{l}\text { Mean visual } \\
\text { acuity } \pm \text { S.D }\end{array}$ & & & \\
\hline
\end{tabular}

$t$ : Independent sample $t$-test.

Table (10): Relation between macular ischemia detected by FFA and macular thickness.

\begin{tabular}{lcccc}
\hline & $\begin{array}{c}\text { Ischemia } \\
\mathrm{n}=9\end{array}$ & $\begin{array}{c}\text { No ischemia } \\
\mathrm{n}=16\end{array}$ & $t$ & $p$-value \\
\hline $\begin{array}{c}\text { Macular thickness (m. } \\
\text { Mean } \pm \text { S.D }\end{array}$ & $464 \pm 271$ & $397 \pm 163$ & 0.644 & 0.535 \\
\hline
\end{tabular}

$t$ : Independent sample $t$-test.

Table (11): Relation between ischemia in the superficial plexus by OCTA and macular thickness.

\begin{tabular}{|c|c|c|c|}
\hline & $\begin{array}{c}\text { Ischemia } \\
\mathrm{n}=17\end{array}$ & $\begin{array}{l}\text { No ischemia } \\
n=13\end{array}$ & $p$-value \\
\hline $\begin{array}{l}\text { Macular thickness (m) } \\
\quad \text { Mean } \pm \text { S.D }\end{array}$ & $459 \pm 208$ & $431 \pm 203$ & 0.3590 .722 \\
\hline \multicolumn{4}{|l|}{$t$ : Independent sample $t$-test. } \\
\hline \multicolumn{4}{|c|}{$\begin{array}{l}\text { Table (12): Relation between ischemia in the deep plexus by } \\
\text { OCTA and macular thickness. }\end{array}$} \\
\hline & $\begin{array}{l}\text { Ischemia } \\
\mathrm{n}=25\end{array}$ & $\begin{array}{l}\text { No ischemia } \\
n=5\end{array}$ & $p$-value \\
\hline $\begin{array}{l}\text { Macular thickness } \\
\quad \text { Mean } \pm \text { S.D }\end{array}$ & $470 \pm 208$ & $316 \pm 53$ & $3.2090 .004 *$ \\
\hline
\end{tabular}

\section{Discussion}

Hayreh S.S., et al., [12] found that in early RVOs, FFA wasn't able to evaluate retinal ischemia in more than $1 / 3$ of the studied cases. They attributed this inability to the presence of retinal hemorrhage. In our study that FFA was not able to evaluate retinal ischemia due to hemorrhage in $23.8 \%$ of early cases.

In our study, OCTA was superior to FFA in detection of macular ischemia in cases of RVO. The difference was statistically significant ( $p$-value $0.001)$. We speculate that this result is partially due to the highly detailed nature of OCT angiograms which detected decreased capillary flow 
where FFA didn't and the swept source technology which allowed better visualization in cases of retinal hemorrhage.

The latter criterion shows the potential of a clear advantage of OCTA in detection of ischemic retinal changes in cases of significant hemorrhage that obscures fluorescein angiograms. This may have a prognostic as well as a clinical value.

This result is consistent with the study of Suzuki N., et al., [13] which reported the same observation of OCTA superiority in evaluation of ischemia in cases of retinal hemorrhage.

Another finding is that OCTA showed ischemia in deep plexus more than superficial plexus. The result was statistically significant ( $p$-value: 0.009 ). This result is consistent with the study of Coscas, et al., [14] . They attributed the difference in perfusion between the superficial and deep plexuses to 2 possible mechanisms. The 1 st is the direct connection between retinal arterioles and superficial capillary plexus which leads to higher oxygen concentrations in the superficial capillary plexus. The 2 nd mechanism is that deep capillary plexus is directly connected to the major retinal veins in the inner retina through transverse venules. This leads to higher hydrostatic pressure and resulting more retinal ischemia. This interesting finding may improve our concepts regarding nature and pathogenesis of retinal ischemia in RVO.

On the other hand, Coscas, et al., [14] concluded in their study that OCTA detected intraretinal cystoid spaces and macular edema in even higher sensitivity than conventional OCT and FFA.

Sellam, et al., [15] and De Carlo, et al., [16] stated that enface OCT scans corresponding to OCT angiograms can be very useful in confirming macular edema in cases where OCT angiograms are not conclusive.

In our study, no such finding of hyperreflective edema in OCT scans was found nor its associated accentuated OCTA signal. However, the typical intraretinal hyporeflective edema in OCT scans appeared in most OCTA cases. There is a partial agreement with Kashani, et al., [17] that OCTA is inferior in detection of macular edema. Our study opposes the results of Coscas, et al., [14] in this point.

It was found that FFA was superior to OCTA in detection of macular edema, even in cases of macular hemorrhage. Although it was statistically insignificant in our study ( $p$-value: 0.390$)$, most probably due to relative small number of cases, this stresses the importance of FFA and its dynamic nature in evaluation of the retina; a very important feature and hard one to be replaced.

Our study also agrees with Sellam A., et al., and de Carlo T.E., et al., in pointing out the potential value of OCT enface scan which was very prominent in our study in differentiating edema from ischemia in some cases and detecting edema in others. This leads to an important point, which is the invaluable importance of reading OCT angiograms head to head with corresponding OCT B scans and enface scans for both complementary and confirmatory values.

Regarding microaneurysms, it was found that FFA is much more sensitive than OCTA in their detection. FFA detected microaneurysms in more cases.

This result may be due to 2 causes. The first is that FFA had a much wider field thus it covered a larger area of affected retina. The second is that OCTA is flow dependent and may miss microaneurysms with slow flow [10]. This is supported by the finding that some of the microaneurysms that were detected by FFA and not by OCTA weren't associated with significant retinal edema.

De Carlo, et al., [10] had the same result as our study. They found that FFA was more sensitive in detection of microaneurysms than OCTA and attributed this finding to slow blood motion in the microaneurysms.

Regarding collateral vessels, FFA and OCTA were equal in detection of collateral vessels, with OCTA showing the level of the vessels being in both and deep capillary plexuses. Suzuki N., et al., [13] reported that both OCTA and FFA detected the same number of collaterals with OCTA being able to locate level of the collateral vessels.

Macular ischemia detected by FFA had a negative relation with VA. This was statistically significant ( $p$-value: 0.009). Coscas, et al., [14] concluded the same result. However, they didn't find the same result for ischemia in superficial and deep plexus although they stated that the deep plexus was generally more ischemic in RVO.

In our study, it was found that ischemia in both superficial and deep capillary plexuses had a statistically significant negative relation with VA ( $p$ value: 0.009 and 0.008 respectively). Ischemia in deep plexus by OCTA had the strongest relation when compared with ischemia in superficial plexus by OCTA and ischemia by FFA. 
This is the same exact result found by Wakabayashi, et al., [18] and Kang, et al., [19]. They reported that ischemia in both superficial and deep plexuses by OCTA was negatively related with VA, with ischemia in the deep plexus having the stronger relation.

A positive weak relation was found between macular thickness and macular ischemia detected by FFA and OCTA in the superficial plexus. However, the result was statistically insignificant ( $p$ values: 0.535 and 0.732 respectively).

On the contrary, a strong positive relationship was found between ischemia in the deep plexus and macular thickness. The result was statistically significant ( $p$-value: 0.004).

Martinet, et al., [20] found a positive relation between macular thickness and ischemia by FFA in RVO, and related both to the BCVA. This was the same result found by Sakimoto, et al., [21] who correlated the macular ischemia by FFA with macular thickness. Both studies had statistically significant results. The difference between our results may be due to the relative small number of cases in our study.

Mastropasqua, et al., [22] reported a statistically significant correlation between superficial and deep plexus ischemia by OCTA and macular thickness. The result was similar to our study regarding deep plexus but not for superficial plexus. This may be due to the previously mentioned cause.

\section{Conclusion:}

OCTA was superior to FFA in detection of macular ischemia. Both modalities were equal in detection of macular edema, collaterals and neovascularizations. FFA was superior in detection of microaneurysms.

\section{References}

1- McINTOSH R.L., ROGERS S.L., LIM L., CHEUNG N., WANG J.J., MITCHELL P., et al.: Natural history of central retinal vein occlusion: An evidence-based systematic review. Ophthalmology, 117 (6): 1113-23 e15, 2010.

2- KLEIN R., KLEIN B.E., MOSS S.E. and MEUER S.M.: The epidemiology of retinal vein occlusion: The Beaver Dam Eye Study. Trans. Am. Ophthalmol. Soc., 98: 13341; discussion 41-3, 2000.

3- MARMOR M.F. and RAVIN J.G.: Fluorescein angiography: insight and serendipity a half century ago. Arch. Ophthalmol., 129 (7): 943-8, 2011.

4- KUBE T., FELTGEN N., PACHE M., HERRMANN J. and HANSEN L.L.: Angiographic findings in arteriovenous dissection (sheathotomy) for decompression of branch retinal vein occlusion. Graefes Arch. Clin. Exp. Ophthalmol., 243 (4): 334-8, 2005.

5- SPAIDE R.F.: Peripheral areas of nonperfusion in treated central retinal vein occlusion as imaged by wide-field fluorescein angiography. Retina., 31 (5): 829-37, 2011.

6- ORTH D.H. and PATZ A.: Retinal branch vein occlusion. Surv. Ophthalmol., 22 (6): 357-76, 1978.

7- LINDBLOM B.: Fluorescein angiography of the iris in the management of eyes with central retinal vein occlusion. Acta. Ophthalmol. Scand., 76 (2): 188-91, 1998.

8- LANG G.E. and HANDEL A.: [Clinical and fluorescein angiography changes in patients with central retinal vein occlusion. A unicenter study of 125 patients]. Klin. Monbl. Augenheilkd., 201 (5): 302-8, 1992.

9- XU K., TZANKOVA V., LI C. and SHARMA S.: Intravenous fluorescein angiography-associated adverse reactions. Can. J. Ophthalmol., 51 (5): 321-5, 2016.

10- De CARLO T.E., ROMANO A., WAHEED N.K. and DUKER J.S.: A review of optical coherence tomography angiography (OCTA). Int. J. Retina. Vitreous., 1: 5, 2015.

11- RISPOLI M., SAVASTANO M.C. and LUMBROSO B.: Capillary Network Anomalies in Branch Retinal Vein Occlusion on Optical Coherence Tomography Angiography. Retina, 35 (11): 2332-8, 2015.

12- HAYREH S.S., KLUGMAN M.R., BERI M., KIMURA A.E. and PODHAJSKY P.: Differentiation of ischemic from non-ischemic central retinal vein occlusion during the early acute phase. Graefes. Arch. Clin. Exp. Ophthalmol., 228 (3): 201-17, 1990.

13- SUZUKI N., HIRANO Y., YOSHIDA M., TOMIYASU T., UEMURA A., YASUKAWA T., et al.: Microvascular Abnormalities on Optical Coherence Tomography Angiography in Macular Edema Associated With Branch Retinal Vein Occlusion. Am. J. Ophthalmol., 161: 126$32 \mathrm{e} 1,2016$

14- COSCAS F., GLACET-BERNARD A., MIERE A., CAILLAUX V., UZZAN J., LUPIDI M., et al.: Optical Coherence Tomography Angiography in Retinal Vein Occlusion: Evaluation of Superficial and Deep Capillary Plexa. Am. J. Ophthalmol., 161: 160-71 e1-2, 2016.

15- SELLAM A., GLACET-BERNARD A., COSCAS F., MIERE A., COSCAS G. and SOUIED E.H.: Qualitative And Quantitative Follow-up Using Optical Coherence Tomography Angiography Of Retinal Vein Occlusion Treated With Anti-vegf: Optical Coherence Tomography Angiography Follow-up of Retinal Vein Occlusion. Retina. 2016.

16- De CARLO T.E., CHIN A.T., JOSEPH T., BAUMAL C.R., WITKIN A.J., DUKER J.S., et al.: Distinguishing Diabetic Macular Edema From Capillary Nonperfusion Using Optical Coherence Tomography Angiography. Ophthalmic Surg Lasers Imaging Retina, 47 (2): 108-14, 2016.

17- KASHANI A.H., LEE S.Y., MOSHFEGHI A., DURBIN M.K. and PULIAFITO C.A.: Optical Coherence Tomography Angiography of Retinal Venous Occlusion. Retina, 35 (11): 2323-31, 2015. 
18-WAKABAYASHI T., SATO T. , HARA-UENO C., FUKUSHIMA Y., SAYANAGI K., SHIRAKI N., et al.: Retinal Microvasculature and Visual Acuity in Eyes With Branch Retinal Vein Occlusion: Imaging Analysis by Optica Coherence Tomography Angiography. Invest. Ophthalmol. Vis. Sci., 58 (4): 2087-94, 2017.

19- KANG J.W., YOO R., JO Y.H. and KIM H.C.: Correlation of Microvascular Structures on Optical Coherence Tomography Angiography with Visual Acuity in Retinal Vein Occlusion. Retina, 2016

20- MARTINET V., GUIGUI B., GLACET-BERNARD A., ZOURDANI A., COSCAS G., SOUBRANE G., et al.: Macular edema in central retinal vein occlusion: Correla- tion between optical coherence tomography, angiography and visual acuity. Int. Ophthalmol., 32 (4): 369-77, 2012.

21- SAKIMOTO S., KAMEI M., SUZUKI M., YANO S., MATSUMURA N., SAKAGUCHI H., et al.: Relationship between grades of macular perfusion and foveal thickness in branch retinal vein occlusion. Clin. Ophthalmol., 7: 39-45, 2013.

22- MASTROPASQUA R., TOTO L., Di ANTONIO L., BORRELLI E., SENATORE A., Di NICOLA M., et al.: Optical coherence tomography angiography microvascular findings in macular edema due to central and branch retinal vein occlusions, 7: 40763, 2017.

\section{مقارنة بين تصوير آوعية قاع العين بإستخدام صبغة الفلوريسين والتصوير المقطعى التوافقى للآوعية الدموينة الدية فى تقييميم الشبكية

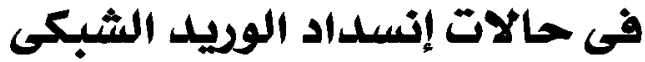

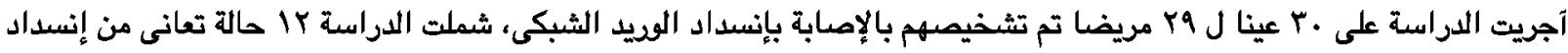

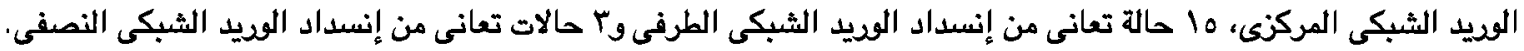

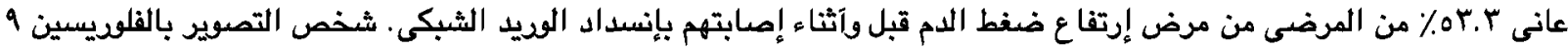

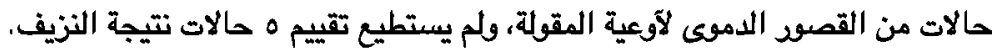

كما وجد التشخيص المقطعى التوافقى قصودا بالدودة الدموية فى الثبكات الوعائية السطحية في IV حالة ولم يجد قصودا فى II حالة.

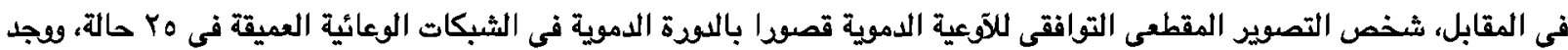

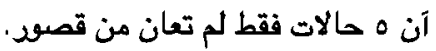

بالنسبة لإرتشاح المقولة، شخص الفلوريسين إرتشاحا بمقولة بr حالة، في مقابل •r حالة شخصا التصوير المقطعى التوافقى للآوعية الدموية.

آما بالنسبة لآمهات الدم الدقيقة، شخص الفلويسين ^ حالات بها، آما التصوير المقطعى التوافقى للآوعية الدموية فشخص ع فقط. تساوى التصوير المقطعى التوافقى للآوعية الدموية والتصوير بإستخدام الفلويسين فى تثخيص الآوعية الصديثة.

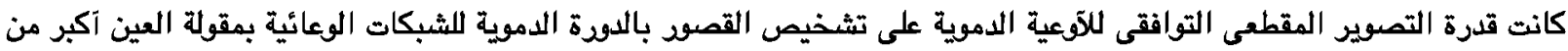

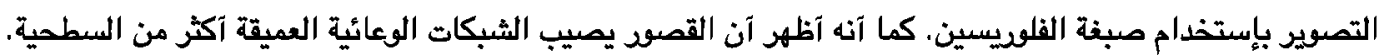

كما كان التصوير المقطعى التوافقى للآوعية الدموية آقدر على تقييم الثبكات الوعائية من التصوير بإستخدام الفلوريسين فى حالات نزيف

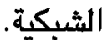

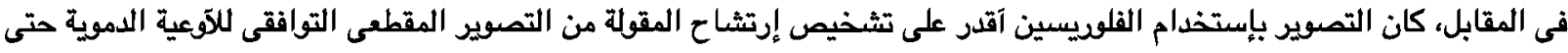
في حالات النزيف الشبكى. كما كان آقدر على ثشخيص آمهات الدم الدقيقة من التصوير المقطعى التوافقى للآوعية الدموية.

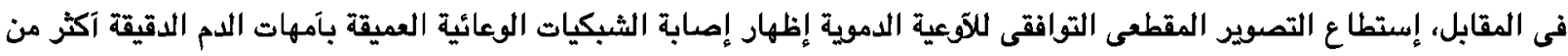
التصوير بإستخدام الفلوريسين، ويرجع هذا إلى خاصية التقسيم الفريدة الخاصة بالتصوير المقطعى التوافقى للآوعية الدموية.

كان التصوير بإستخدام الفلوريسين والتصوير المقطعى التوافقى للآوعية الدموية متساويين في قدرتهما على تشخيص الآوعية الصديثة. 